\begin{tabular}{|c|c|c|}
\hline & PORT SAID ENGINEERING RESEARCH JOURNAL & Faculty of Engineering - Port Said University \\
\hline
\end{tabular}

\title{
A Roadmap for Establishment of an Early Warning System for Nile Water Quality in Egypt
}

\author{
Mohamed E. Gabr \\ Received: 27 October 2019; Accepted: 14 July 2020
}

\begin{abstract}
The Nile River is the lifeblood of Egypt. The necessity to rationalize Nile's water uses and protecting from pollution and accidents are urgent issues. Continuous monitoring and utilizing the early warning system (EWS) have become important tools to protect and manage water sources for sustainable development. The aim of this study is to propose and design of an EWS in real-time for Nile's water in Egypt in order to mitigate the water pollution disaster by terrorism and accidents. To achieve this objective, (1) the EWS basic structure regarding risk knowledge, monitoring system, active communication of information, and the plans for readiness and response (case study the Rhine River) are reviewed, (2) the current Nile's water quality monitoring stations, and the challenges that encounter the implementation of the EWS in Egypt are examined, and (3) the proposed EWS is designed and a road map to establish the EWS is identified. The roadmap describes a process in four steps; a start-up by a letter of interest from all concerned ministers, organizational setup, implementation and testing, and continuous improvement. Establishment of a steering committee consisting of the main ministries recruited from the National Council for the protection of the Nile is a necessity as it determines the responsibilities and the corrective actions, and consequently, optimizing the EWS. The current capacity of the laboratories in Egypt is sufficient; only the monitoring program should be changed. The proposed EWS will provide a sufficient information database for the decision-makers in sustainable water management.
\end{abstract}

KEYWORDS: Nile Water Quality; Early Warning System; Water Pollution Risk; Egypt Water Management

\section{INTRODUCTION}

Degradation of freshwater quality globally and especially in Egypt is becoming increasingly alarming regarding salinity, trace elements, toxic organic compounds, illegal spills, and unknown accidents that need a big cost for treatment [1]. Egypt suffers from a shortage of water resources as it has a dry climate, scarce rain, and a constant share of the Nile's water (55.5 Billion $\mathrm{m}^{3}$ per year $(\mathrm{BCM} / \mathrm{Y}))$ according to the 1959 agreement [2]. Nowadays, in Egypt, there is a big gap between the water supplies, and the water demands because of population growth, agricultural expansion, industrial development, and rising standards of living. Currently Egypt reuses more than $13.5 \mathrm{BCM} / \mathrm{Y}$ of the agriculture drainage water in the agriculture sector in order to overcome this water shortage $[3,4]$. In addition, the demand on groundwater uses were increased [3,5]. Ministry of Water Resources and Irrigation (MWRI) in Egypt stablished a National Water Resources Plan in 2017 to overcome the water shortage to the year 2037, as it is planned to construct desalination, water stations, and lining the irrigation canal networks (to minimize water losses). In addition, improving the irrigation efficiencies of the old lands, improving the current efficiencies of the wastewater treatment plants, and constructing new wastewater treatment plants $[6,7,8]$. Many challenges face Egypt water resources quantity and quality such as,

\footnotetext{
${ }^{1}$ Civil Engineering Department, Higher Institute for Engineering and Technology, New Damietta, Ministry of Higher Education, Egypt; email: m_egabr@yahoo.com.

DOI: $10.21608 /$ pserj.2020.18756.1014
}

the impact of the urbanization activities on the Nile's water quality as, the water becomes less healthy for the river life. In addition, Egypt Nile's water share will subject to decrease by the erection of the Grand Ethiopian Renaissance Dam, which, consequently reflects on a decrease in water supplies, and the river dilution power of regarding the pollutants $[9,10]$. Consequently, safeguarding of the Nile's water from pollution through continuous monitoring of the location and advancing early warning system became a very necessary issue. In recent years, the EWS have been a good alternative solution for water resource managers. It is a combined system for internet monitoring, collection of data, interpretation, analysis, and reporting of the monitoring data. These data can help the decision-makers to take decisions at an early stage to safeguard the public health and the environment $[11,12]$. A complete early warning system is comprised of five interrelated elements: risk information, adequate monitoring, alarm service, dissemination and communication, and response capacities [13, 14]. Sensors perform part of the water quality monitoring for the basic physicochemical parameters such as hydrogen ion concentration $(\mathrm{pH})$, temperature, hydraulic conductivity (EC), dissolved oxygen (DO), discharges, and turbidity [15]. The establishment of the EWS for Nile waters in Egypt challenges some problems, for example the application of the law does not provide enough detail to operate effectively against water quality disasters, and detection of spills of pollution is currently too difficult due to the fact that monitoring networks are fragmented in time and 
space. The monitoring of the Nile's water quality in Egypt is carried out by four ministries: Ministry of Health $(\mathrm{MoH})$, Ministry of Housing (through the Holding Company for Water and Wastewater (HCWW), Ministry of Water Resources and Irrigation (MWRI), and Ministry of Environment (through the Egyptian Environmental Affairs Agency (EEAA)). The Ministry of Health (MoH) is responsible for the analyzing of the water samples and to inform the other ministries to take their roles when using this data. Accordingly, pollutant measurement methods and time are very important issues to handle disasters. For example, oil, grease, and Nitrate $\left(\mathrm{NO}_{3}\right)$ can be measured quickly. But, illegal spills or unknown accidents, which are identified through laboratory analyses, are identified after up to more than a week as laboratory capabilities and facilities that can react fast are needed to adequately handle water quality disasters. Consequently, improvement in the cooperation and coordination of water quality monitoring stations between the four responsible ministries is necessary as there is a lot of overlap in the water quality monitoring activities. In some cases, the laboratory instruments and employees trained on laboratory equipment are not enough as the results often differ between ministries, leading to more problems in cooperation. Therefore, construction of a protocol for communication between the concerned ministries in case of an oil spill or accident happens is a priority issue to transfer and manage the required information to handle such a disaster at the earliest time. The aim of this research is to propose and design an active EWS in real-time to ensure the safety of Nile water in Egypt and to mitigate the water pollution disaster by terrorism and accidents. In order to achieve this objective, (i) it is reviewed the EWS basic structure regarding risk knowledge, monitoring system, active communication of information, and the plans for readiness and response, (ii) It is assessed the current water quality monitoring stations in the Nile and the current problems facing the early warning system implementation, (iii) it is designed the proposed Nile EWS, and (iv) it is recommended a road map for the EWS implementation for the Nile water quality in Egypt utilizing the state monitoring processes and providing assistance in problem analysis and resolution.

\section{MATERIALS AND METHODS}

The Nile River is the longest river in the world (6650 $\mathrm{km}$ ) and its basin has an area of about 1.1 million square miles. It comprises eleven riparian countries, Egypt, Sudan, Republic of South Sudan, Ethiopia, Kenya, Uganda, Tanzania, Rwanda, Democratic Republic of Congo, Burundi, and Eritrea, Fig. 1. In Egypt the Nile River is the major freshwater source. About $95 \%$ of Egyptians live in the Nile Valley depend on the Nile freshwater for all activities. Egypt current water supply is about $60 \mathrm{BCM} / \mathrm{Y}$ distributed as $55.5 \mathrm{BCM} / \mathrm{Y}$ from the Nile, $2.5 \mathrm{BCM} / \mathrm{Y}$ from deep groundwater, and 2.5 $\mathrm{BCM} / \mathrm{Y}$ from shallow groundwater and desalinated water $[3,16]$. On the other hand, the total water demand was about $80 \mathrm{BCM} / \mathrm{Y}$ in 2017 distributed as $61.35 \mathrm{BCM} / \mathrm{Y}$ for agriculture sector, $10.75 \mathrm{BCM} / \mathrm{Y}$ for drinking, 5.4 $\mathrm{BCM} / \mathrm{Y}$ for the industrial sector, and $2.5 \mathrm{BCM} / \mathrm{Y}$ as evaporation losses [16]. Non-conventional water resources such as reuse of treated wastewater and agricultural drainage water of good quality (13.5 BCM/Y) are the future key solutions to fulfil the shortage of water supplies [3].

\subsection{Current water quality monitoring in the Egypt Nile}

Table 1 summarizes the number of monitoring stations, sampling frequency, and the water quality parameters. In addition, Fig. 2A shows the monitoring stations distribution. The HCWW has more than 450 water quality station for drinking water with a rate of 30 sample day $^{-1}$ alkalized for total water quality parameters. The HCWW transfer information using supervisory control and data acquisition (SCADA) system to support decision makers, sending data by SMS and E-mail (Tables 1 and 2). The MWRI has 285 monitoring stations distributed as 15 stations for Outfalls to Northern Lakes, 4 stations for Lake Naser, Nile Delta (50 stations for irrigation canals and116 stations for drains), Nile River (48 stations for Nile water, 9 stations for irrigation canals intakes and 43 stations for drains outlets) (Fig. 2B) [10].

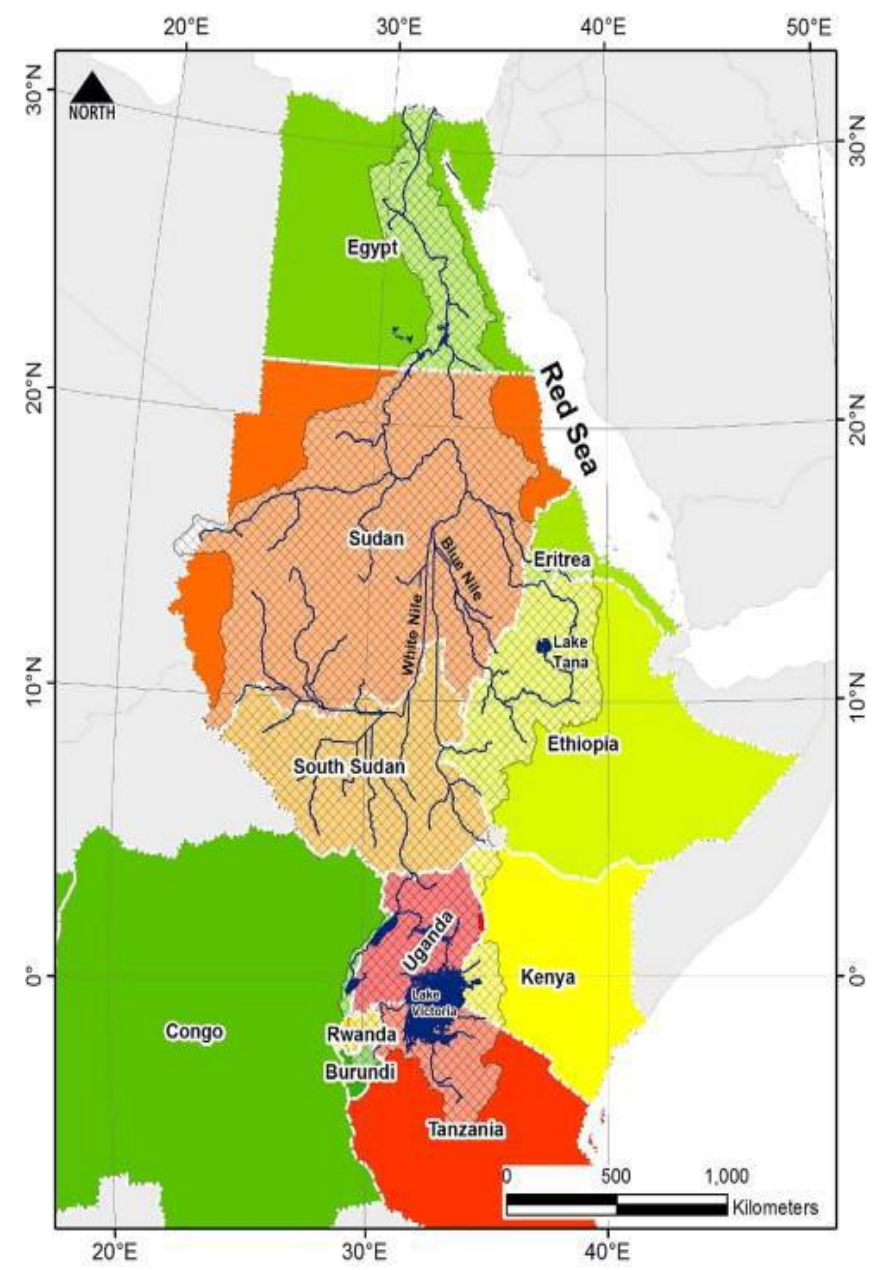

Fig. 1: Nile River Basin 


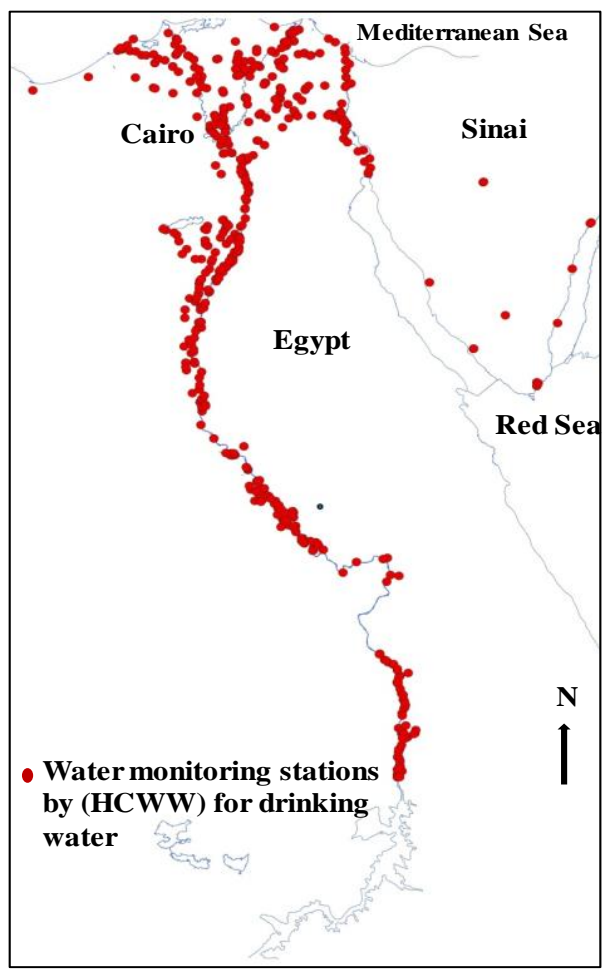

A. Monitoring stations for drinking water by the HCWW

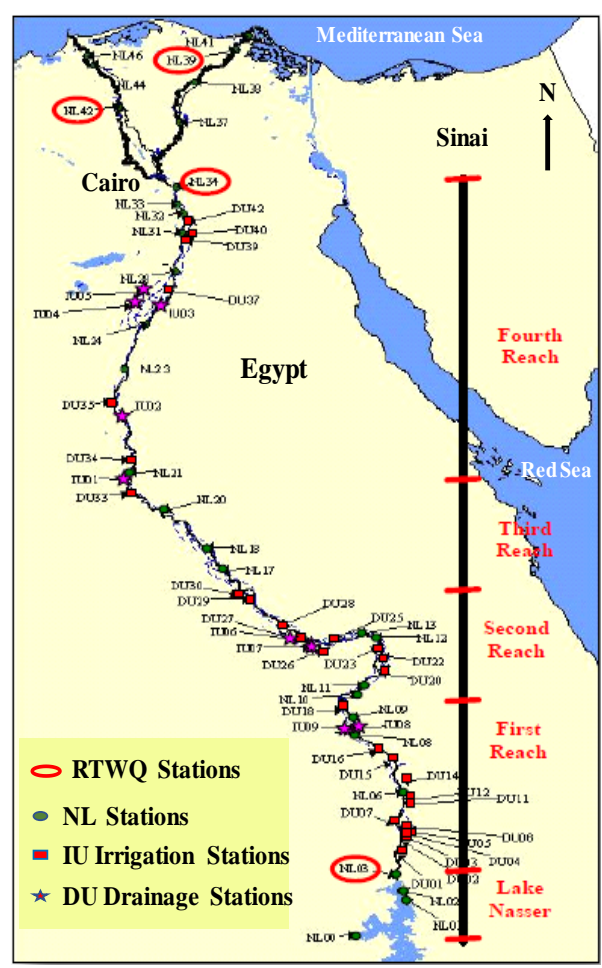

B. Monitoring stations for Nile, and canals and drains network.

Fig. 2: Water quality monitoring stations.

Table: 1 Current water quality monitoring of the Nile in Egypt carried out by ministries.

\begin{tabular}{|c|c|l|l|c|c|}
\hline Institutions & $\begin{array}{c}\text { No. of } \\
\text { Stations }\end{array}$ & \multicolumn{1}{|c|}{ Frequency } & \multicolumn{1}{|c|}{ Purpose of monitoring } & $\begin{array}{c}\text { No. } \\
\text { of } \\
\text { Labs }\end{array}$ & $\begin{array}{c}\text { No of } \\
\text { samples } \\
\text { per day }\end{array}$ \\
\hline HCWW & 450 & $\begin{array}{l}\text { All parameters } \\
\text { every two weeks in } \\
24 \text { central labs 3 } \\
\text { parameters daily. }\end{array}$ & $\begin{array}{l}\text { Main as technical information about the water } \\
\text { purification process and to ensure compliance } \\
\text { with the drinking water standards. }\end{array}$ & 24 & 30 \\
\hline MRWI & 285 & $\begin{array}{l}\text { All parameters } \\
\text { every 6 months. }\end{array}$ & $\begin{array}{l}\text { Monitoring accordingly to Law 48 and (Egypt } \\
\text { decree, 92/2013) which defines water quality } \\
\text { standards for different uses. }\end{array}$ & 1 & $<1$ \\
\hline MoH & $>1000$ & $\begin{array}{l}\text { All parameters } \\
\text { monthly. }\end{array}$ & $\begin{array}{l}\text { To check compliance of HCWW for the } \\
\text { monitoring the river Nile quality. Discharge of the } \\
\text { WWTP and industries is being monitored for study } \\
\text { purpose. all according to Low 48 and (Egypt } \\
\text { decree, 92/2013). }\end{array}$ & 12 & $>30$ \\
\hline EEAA & 69 & $\begin{array}{l}\text { All parameters } \\
\text { except pesticides } \\
\text { every 3 months. }\end{array}$ & $\begin{array}{l}\text { Environmental quality and ecological effects. For } \\
\text { environmental permits (data from MoH is used) }\end{array}$ & 1 \\
\hline
\end{tabular}

HCWW, Holding Company for Water and Wastewater; MWRI, Ministry of Water Resources and Irrigation; MoH, Ministry of Health; and EEAA, Egyptian Environmental Affairs Agency.

Table 2. Currently used data transfer system.

\begin{tabular}{|c|l|}
\hline Organization & \multicolumn{1}{c|}{ Description } \\
\hline MWRI & $\begin{array}{l}5 \text { stations along the Nile river transfer the data through the (GSM) system to } \\
\text { the main office at MWRI. }\end{array}$ \\
\hline HCWW & $\begin{array}{l}\text { Uses (SCADA) system to support decision makers, sending data by (SMS) and } \\
\text { E-mail }\end{array}$ \\
\hline
\end{tabular}

(SCADA), supervisory control and data acquisition; (GSM), global system for mobile communications; and (SMS), short message service.

Daily water quality monitoring for all stations was carried out in terms of temperature, total dissolved solids (TDS), turbidity, dissolved oxygen (DO), $\mathrm{pH}$ and electrical conductivity EC. In addition, measurement of upstream water level, downstream water level, and operating pump unit's status for water distribution management. There are four real-time water quality monitoring stations (RTWQ stations) at Nile in Aswan, at Nile in Ismailia canal intake, EL-Salam Canal intake at Damietta Branch and Benowvar at Rossetta Branch. At these RTWQ stations 
the monthly water quality samples were taken and analyzed for the water quality parameters physical parameters (temperature, odor, color and turbidity), chemical parameters (EC, TDS, $\mathrm{pH}$, cations ( $\mathrm{Na}, \mathrm{K}, \mathrm{Ca}$, $\mathrm{Mg}$ ), and anions $\left(\mathrm{Cl}, \mathrm{SO}_{4}, \mathrm{HCO}_{3}, \mathrm{CO}_{3}\right)$. The oxygen budget (DO, BOD and COD), nutrients $\left(\mathrm{NH}_{4}, \mathrm{NO}_{3}\right.$ and $\mathrm{P}_{2} \mathrm{O}_{5}$ ), heavy metals ( $\mathrm{Fe}, \mathrm{Mn}, \mathrm{Pb}, \mathrm{Cu}$ and $\mathrm{Zn}$ ), and microbiology (total coliform). The water samples transferred to the Center Laboratories for Environmental Quality Monitoring, National Water Research Center, MWRI, Cairo, to determine water quality parameters [10].

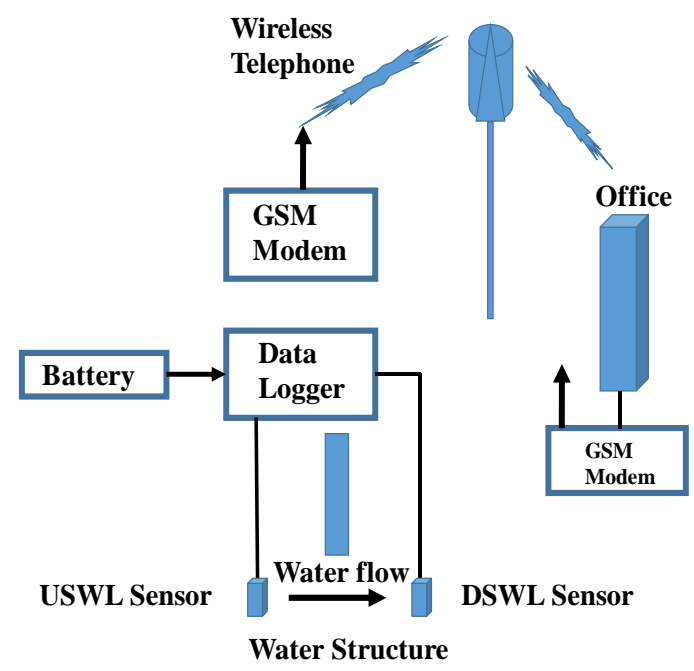

(A) Telemetry system components

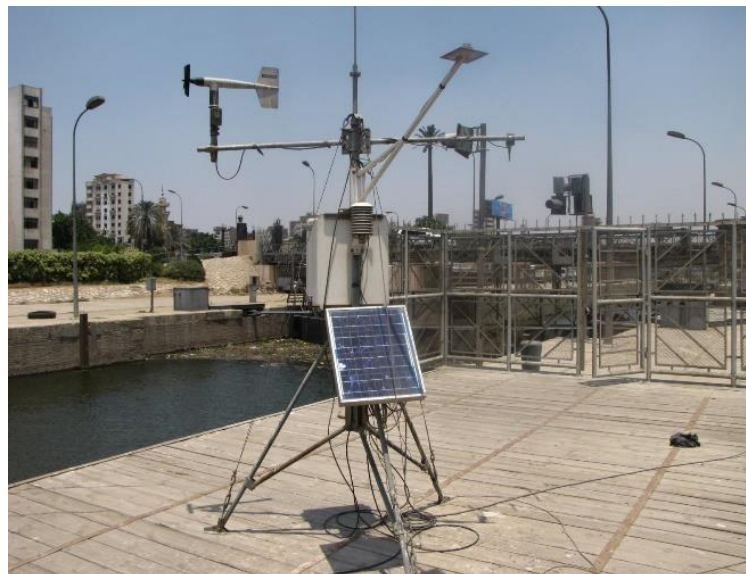

(B) Monitoring station at Ismailia canal intake in Cairo.

Fig. 3: Telemetry system components for Nile water quality monitoring in the MWRI.

The analysis time usually larger than one week. Water quality information are transferred through the telemetry system to the main office at MWRI (Table 2). The MWRI faces several challenges to safeguard Egypt water sources against the spread of non-point pollution sources coming from the urban areas (not complete sewerage system), random sub-urban, rural areas (not enough sewerage system), and livestock production. In addition, point pollution sources such as industrial areas (inadequately wastes treated) and wastewater treatment plants (low treatment efficiency). Therefore, the MWRI has a telemetry system to assess water quality and improving routine monitoring. It consists of on site: data Logger, GSM/GPRS modem, water level sensors, power supply, solar cell, and battery (NEMA) box (Fig. 3A). The Global System for Mobile Communications (GPRS) functions are (i) write, read and delete SMS messages, (ii) monitor the signal strength, (iii) send SMS messages, (iv) read, write and search phone book entries, and (v) monitor the charging status and charge level of the battery. GSM (Global System for Mobile Communications) is created to describe the protocols for second-generation (2G) digital cellular networks used by mobile phones. At irrigation districts in the office of General Directorates, Telemetry Department: computer system equipped with S/W and GSM/GPRS modem, and water distribution manager. At the MWRI centre office: Servers and GSM/GPRS Modems. Data types are real-time data, communication, historical data, dedicated access point name (APN), and supports up to the GPRS-edge. Fig. 3B shows telemetry station at the Nile for Ismailia Intake in Cairo.

\subsection{Basic structure of the early warning system for water sources}

\subsubsection{Risk Knowledge}

Knowledge of the risk disaster contributes to the enhancement of the processes of risk adaptation, reduction and management. A disaster is an event that has a severe effect on the population's daily activities, concerning social and material damages, and has environmental and economic impacts [14]. There is an important conceptual distinction between two probabilities of risk as, (i) The risks with a high probability of occurrence, but have low consequences such as epidemiological and diseases studies of long-term exposure to low levels of contaminants, and (ii) the risks with a low probability of occurrence, but have significant consequences such as a terrorist who throw the toxic chemicals to pollute the watercourse and to destroy the aquatic life and the health of millions of people. In April 2015, a ship carrying 500 tons of phosphate sank in the Nile in Qena Governorate after hitting a bridge; and the HCWW announced an emergency state in Assiut, Qena, and Sohag governorates over the accident. In September 2010, in southern Egypt in Aswan city (855 km from Cairo), a docked barge leaked about 100 tons of gasoline into the Nile River, the docked barge inclined and partially immersed due to the drop in water levels, permitting the fuel to leak out. The HCWW closed the water purification plants to prevent contaminated water to enter the purification filters. The risks with a low probability of occurrence, but have significant consequences such as accidents and terrorist cannot be avoided, but the establishment of a safety culture and strong response mechanisms lead to the rapid handling of risk mitigation. MWRI has laid out water quality standards for treating wastewater to safeguard freshwater watercourses (Egypt Decree 92/2013) [17], and WHO, 2006 [18], and USEPA, 2012 [19] have recommended standards for safe reuse of wastewater in irrigation practices. 


\subsection{Early Warning Monitoring}

Water quality monitoring system is essential for three reasons: detection of unknown spills or accidents, determining the extent of existing water quality disasters, and learning and optimizing water quality management and analysis of water quality disasters. To assess the capacities of current water quality monitoring stations in Egypt it is compared with the Rhine river early warning system as: Sampling frequency in Egypt is low frequency ( 2 weeks) at more than 400 monitoring stations along the Nile. In Rhine, high frequency $\left(2\right.$ day $\left.^{-1}\right)$ at 7 monitoring stations along the Rhine [21], Also, In Rhine biological monitoring (Algae, Daphnia, Mussel) is made. In the Rhine, screening of organic contaminants by Gas Chromatography-Vacuum Ultraviolet Spectroscopy (GC-UV) is additionally done [22]. The main differences between monitoring program of raw and treated drinking water by Egypt and Dutch part of the Rhine can be summarized as follows (Table 3):

- In Netherlands, all functions are carried out by one ministry and results are used by many stakeholders. However, the Rhine EWS consists of four countries.

- In Egypt, all functions are carried out by four institutions and results are used by many stakeholders.

- In Netherlands, locations and sampling frequency, high frequency 1 monitoring point per two days travel time.

- In Egypt, locations and sampling frequency, low frequency ( 2 weeks) at more than 400 monitoring points in the Nile.

- Netherlands: samples for drinking water, few times per year depending on size and water quality issues in individual drinking water stations, according to the European Water Framework Directive [23].

- In Egypt, monitoring stations for drinking water sampling installed at large drinking water intakes at the Nile HCWW.

- In Netherlands, Biological monitoring (algae, Daphnia, Mussel): done.

- In Egypt, Biological monitoring (algae, Daphnia, Mussel): non.

- In Netherlands, screening of organic contaminants by (GC-UV): done.

- In Egypt, screening of organic contaminants by (GCUV) stabilizers: non.

- The main difference between reporting time after sampling is that Nile monitoring results are reported after several days instead of at the same day in the Rhine EWS monitoring.

\subsubsection{Communication and responsibility}

Sending warnings are a critical step between forecasting and action. Communication takes place when the information is received and understood, while, dissemination refers to sending the warning [24]. Dissemination of alerts should be worked out in protocols through several channels in order to decrease delays in supply to the end-users, ensuring it reaches for many people as possible and taking the required measure to prevent these channels from failure [25]. Communication protocols should be simple and short and the communication itself should be traceable [24]. In the Rhine River a simple, format of three pages with very limited for details is used and communication is done by fax $[21,26]$. When the information are not delivered, damage to other stakeholders may occur. Annex 1 summarizes proposed a fax communication sheet for warning system for Egypt Nile's water quality. Annex 2 summarizes proposed reporting scheme for passing on report.

Table 3. A comparison between Rhine River and Nile River in Egypt regarding the early warning system monitoring.

\begin{tabular}{|l|l|l|}
\hline Parameters & $\begin{array}{c}\text { Rhine River } \\
\text { EWS }\end{array}$ & $\begin{array}{c}\text { Egypt Nile's } \\
\text { EWS }\end{array}$ \\
\hline $\begin{array}{l}\text { Locations and } \\
\text { sampling } \\
\text { frequency }\end{array}$ & $\begin{array}{l}\text { High } \\
\text { frequency 1 } \\
\text { monitoring } \\
\text { point per two } \\
\text { days travel } \\
\text { time }\end{array}$ & $\begin{array}{l}\text { Low frequency } \\
\text { (2 weeks) at } \\
\text { more than 400 } \\
\text { monitoring } \\
\text { points in the } \\
\text { Nile. }\end{array}$ \\
\hline $\begin{array}{l}\text { Biological } \\
\text { monitoring } \\
\text { (algae, Daphnia, } \\
\text { Mussel) }\end{array}$ & Done & \multicolumn{1}{c|}{ Non } \\
\hline $\begin{array}{l}\text { Screening of } \\
\text { organic } \\
\text { contaminants by } \\
\text { (GC-UV) }\end{array}$ & Done & Non \\
\hline $\begin{array}{l}\text { Reporting time } \\
\text { of monitoring } \\
\text { results }\end{array}$ & Same day & Several days \\
\hline
\end{tabular}

(GC-UV), Gas Chromatography-Vacuum Ultraviolet Spectroscopy

\subsubsection{Readiness and response}

Disaster readiness comprises all the activities essential for a community to react to an event, e.g. unusual rise in the concentrations of chemical, physical, and bacteriological parameters, in cases of a significant excess of boundary values for the design discharge, releases of substances during transportation that permits serious failure. It is essential for the community to receive and correctly understand issues alerts, so they may draw the needed conclusions for actions to be taken, such as alerting firefighters and local police. Preparedness and response key actions are community based and grassroots organization, technical agencies with specialized knowledge of hazards, Universities, schools, informal education sector, media (radio, television, prints, and online), and international, national and local disaster management agencies [13].

\section{DISCUSSION}

\subsection{Characteristics of the Nile EWS}

The main pillar of the EWS is communication. When a shipping accident happens, all relevant stakeholders are informed in time, e.g. by the river authority or the police. This means one ministry can increase downstream 
monitoring in order to detect effects. Another ministry can identify the types and loads of the ships involved and determine whether the ship is losing oil or its load. A third ministry can close down downstream drinking water intakes immediately until the risks are identified. Ministries can in a protocol, also be responsible for certain actions that should always be undertaken. When an industrial spill or accident happens near the river and all stakeholders are informed in time, e.g. by the fire department, the above actions can be undertaken in a similar matter. A ministry such as the ministry of industry may be involved as well in such a situation. However, when an illegal spill occurs, authorities will not be notified. For this, detection by early warning monitoring is crucial to warn relevant stakeholders. Here the ministry that carries out the monitoring will inform the other ministries. EWS consists of communication protocols and early warning monitoring. Monitoring is also important for the management of water quality disasters as many lessons can be learned: Using monitoring it will be known if the EWS is working when a real accident happens: does the fire department warn the authorities adequately and in time or it is found out an accident happened by finding pollutants downstream? Using monitoring spills can be quantified, the frequency, the types of pollutants/incidents and the effects are monitored. Consequently, effects of policy to prevent disasters can be monitored, the selfcleaning capacity of the river can be quantified, and the occurrence of unknown contaminants can be quantified and later be identified, causes can be found and a policy can be made for prevention. On analysis, investment costs can be limited, depending on the pilot stage techniques that can be added. Evaluation of the current water quality monitoring is needed, even when budgets would be available to make the EWS monitoring possible as an addition to the current monitoring program. It is likely that a large part of the current monitoring would, after evaluation, be considered less effective in reaching the general monitoring goals.

\subsubsection{Proposed EWS stations and frequency}

The average flow velocity of the Nile in Egypt is about $100 \mathrm{~km} \mathrm{day}^{-1}$. The distance from Aswan to the Delta nearly $950 \mathrm{~km}$. If the daily water samples are taken every $10 \mathrm{~km}$ at one point in time in a river reach of $100 \mathrm{~km}$, one might as well sample the water quality at a fixed station every 2.4 hours. From this observation, it is concluded that using fewer monitoring points to monitor water quality at a more regular basis (e.g. twice per day) will (i) reduce costs of sampling and sample handling (especially if the lab is at the river), (ii) ease the interpretation of river water quality data, (iii) decrease the reaction time, and (iv) easier and earlier detection. From a statistical point of view in which the chance of detecting spills/accidents in a monitoring system is calculated, the following question can be answered: What will be the chance of detecting a spill that passes in one day on the first day (within a river segment of $100 \mathrm{~km}) ? 1$ day $=100 \mathrm{~km}$ long plume $=50$ monitoring points (sampling point ever $2 \mathrm{~km}$ ). These are measured randomly every month: the plume will be detected in 1.66 sampling points on average. Sometimes it will be detected in more sampling points, sometimes it will not be detected. When all 50 samples are taken on the same day the chance of detection is one in 30 (3.3\%). Other monitoring with two samples per day, it will be detected two times always. Therefore, optimum EWS locations will have to be found downstream of areas that are considered to have the highest risk (cities) in order to get the earliest warning possible and to have the longest possible reaction time to the next city (with many inhabitants) downstream as in Abou Sunbul, Idfu, Qena, Asyut, Minya, Cairo, Damanhur, Tanta, and Mansora (Fig. 4). In this way, maximum amount of people can be protected from risks. These stations are, of course, preferably laboratories already located next to the Nile so that continuance sampling of river water is possible. When using only existing techniques on analysis, investment costs can be limited, depending on the pilot stage techniques can be added. Evaluation of the current water quality monitoring is needed, even when budgets would be available to make the EWS monitoring possible as an addition to the current monitoring program. It is likely that a large part of the current monitoring would, after evaluation, be considered less effective in reaching the general monitoring goals.

\subsubsection{Parameters}

Current monitoring programs only focus on the main substances/metals and main pesticides. Biological monitoring (Algae, Daphnia, Mussel) is considered as very useful to judge toxicity of the river water. There is a gap in knowledge on this aspect (what will happen?). Screening methods are currently not used. (GC-UV) screening can be used to identify unknown organic pollutants: it is cheap, fast and substances can later be identified by (GCMS) [27]. Table 4 summarizes the proposed threshold of the main water quality parameters according to Egypt decree 92/3013 (MWRI). We propose set class 3 as the early warning boundary value. Early warning corresponding relationship is Class 3 yellow warning, Class 4 orange warning, and Class 5 red warning.

\subsubsection{Drinking Water}

Sampling and analysis frequency by both Holding company and by the Ministry of Health is considered high, especially when compared with the Dutch situation. The number of samples would fit an EWS better than considered appropriate for drinking water production in e.g. the EU Water Framework Directive.

\subsubsection{Organizational Aspects of EWS}

The Nile EWS should be organized as follows:

- A steering committee consisting of the main ministries recruited from the National Council for the Protection of the Nile that determines responsibilities 


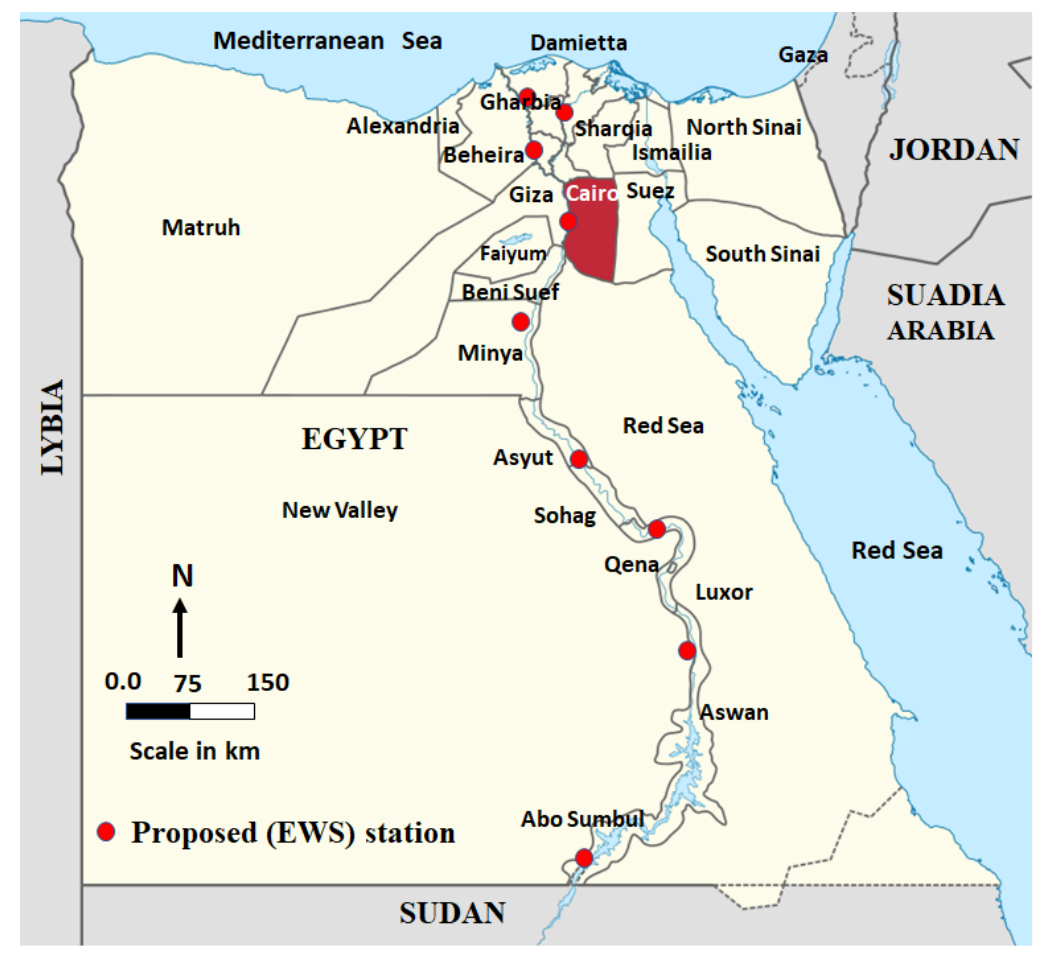

Fig. 4: Proposed monitoring stations

Table 4. Proposed threshold of the main water quality parameters.

\begin{tabular}{|c|c|c|c|c|c|c|}
\hline \multirow[t]{2}{*}{ Item } & \multirow[t]{2}{*}{ Units } & \multicolumn{5}{|c|}{ Water classification } \\
\hline & & Class1 & Class 2 & Class 3 & Class 4 & Class 5 \\
\hline $\mathrm{pH}$ & - & \multicolumn{5}{|c|}{$6.5-8.5$} \\
\hline $\mathrm{DO} \geq$ & $\mathrm{mg} \mathrm{L}^{-1}$ & 7.5 & 6 & 5 & 3 & 2 \\
\hline $\mathrm{COD} \leq$ & $\mathrm{mg} \mathrm{L}^{-1}$ & 15 & 15 & 20 & 30 & 40 \\
\hline $\mathrm{COD} \mathrm{Mn} \leq$ & $\mathrm{mg} \mathrm{L}^{-1}$ & 2 & 4 & 6 & 10 & 15 \\
\hline $\mathrm{BOD}_{5} \leq$ & $\mathrm{mg} \mathrm{L}^{-1}$ & 3 & 3 & 4 & 6 & 10 \\
\hline $\mathrm{NH}_{3} \mathrm{~N} \leq$ & $\mathrm{mg} \mathrm{L}^{-1}$ & 0.15 & 0.5 & 1.0 & 1.5 & 2.0 \\
\hline $\mathrm{TN} \leq$ & $\mathrm{mg} \mathrm{L}^{-1}$ & 0.2 & 0.5 & 1.0 & 1.5 & 2.0 \\
\hline $\mathrm{TP} \leq$ & $\mathrm{mg} \mathrm{L}^{-1}$ & 0.02 & 0.1 & 0.2 & 0.3 & 0.4 \\
\hline Fecal Coliform $\leq$ & $100 \mathrm{~mL}^{-1}$ & 200 & 2000 & 10000 & 20000 & 40000 \\
\hline $\mathrm{Se} \leq$ & $\mathrm{mg} \mathrm{L}^{-1}$ & 0.01 & 0.01 & 0.01 & 0.02 & 0.02 \\
\hline $\mathrm{S} \leq$ & $\mathrm{mg} \mathrm{L}^{-1}$ & 0.05 & 0.1 & 0.2 & 0.5 & 1.0 \\
\hline $\mathrm{F} \leq$ & $\mathrm{mg} \mathrm{L}^{-1}$ & 1.0 & 1.0 & 1.0 & 1.5 & 1.5 \\
\hline $\mathrm{Cu} \leq$ & $\mathrm{mg} \mathrm{L}^{-1}$ & 0.01 & 1.0 & 1.0 & 1.0 & 1.0 \\
\hline $\mathrm{Zn} \leq$ & $\mathrm{mg} \mathrm{L}^{-1}$ & 0.05 & 1.0 & 1.0 & 2.0 & 2.0 \\
\hline $\mathrm{Hg} \leq$ & $\mathrm{mg} \mathrm{L}^{-1}$ & 0.00005 & 0.00005 & 0.0001 & 0.001 & 0.001 \\
\hline As $\leq$ & $\mathrm{mg} \mathrm{L}^{-1}$ & 0.05 & 0.05 & 0.05 & 0.1 & 0.1 \\
\hline $\mathrm{Cr}(\mathrm{VI}) \leq$ & $\mathrm{mg} \mathrm{L}^{-1}$ & 0.01 & 0.01 & 0.05 & 0.05 & 0.1 \\
\hline $\mathrm{Cd} \leq$ & $\mathrm{mg} \mathrm{L}^{-1}$ & 0.001 & 0.005 & 0.005 & 0.005 & 0.01 \\
\hline $\mathrm{CN} \leq$ & $\mathrm{mg} \mathrm{L}^{-1}$ & 0.005 & 0.05 & 0.02 & 0.5 & 0.2 \\
\hline $\mathrm{Pb} \leq$ & $\mathrm{mg} \mathrm{L}^{-1}$ & 0.01 & 0.01 & 0.05 & 0.05 & 0.1 \\
\hline Oil $\leq$ & $\mathrm{mg} \mathrm{L}^{-1}$ & 0.05 & 0.05 & 0.05 & 0.5 & 1.0 \\
\hline LAS $\leq$ & $\mathrm{mg} \mathrm{L}^{-1}$ & 0.2 & 0.2 & 0.2 & 0.3 & 0.3 \\
\hline Phenol $\leq$ & $\mathrm{mg} \mathrm{L}^{-1}$ & 0.002 & 0.002 & 0.005 & 0.01 & 0.1 \\
\hline
\end{tabular}

TN, total Nitrogen; TP, total phosphors; and LAS, Linear Alkyl Benzene Sulphonate 
Organizational support. implementation plan support. Gap Analysis Support.

\section{.}

Step 2 : Organizational Setup and Planning
Start up steering committee
Developed unit

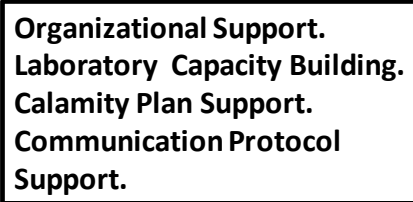

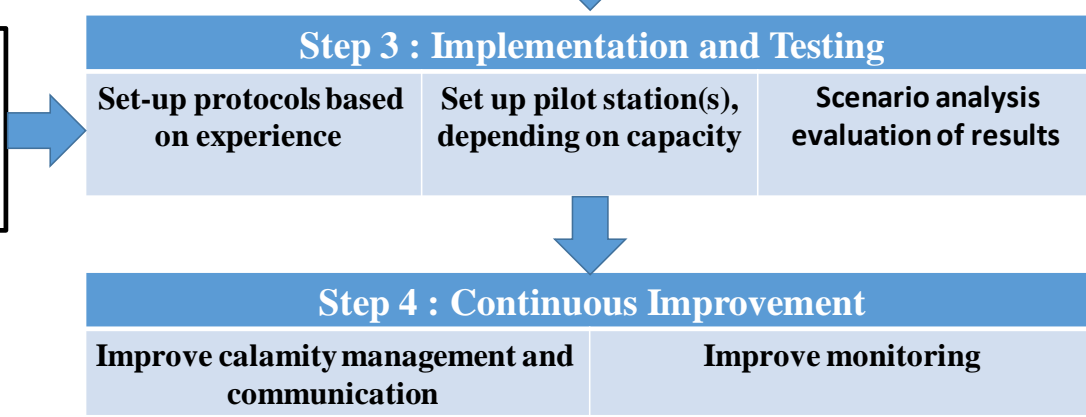

Fig. 5: Process of EWS for the Nile and that can make corrective actions and that can optimize the EWS.

- An operational unit linking between the ministries, that can practically prepare the establishment of an EWS, evaluate the functioning of the EWS, and can design or redesign parts of the existing EWS in

- order to make recommendations to the steering committee.

- Operational units within these institutions, are responsible for the tasks and responsibilities given to each institution.

\subsection{Roadmap towards the implementation of an EWS for the Nile}

The implementation of the EWS for the Nile comprises aspects of organizational, financial and technical nature. The roadmap for the EWS describes a process in four steps (Fig. 5): 1. start-up, 2. organizational set-up, 3. implementation and testing, and 4. continuous improvement.

\subsubsection{Start-up}

To develop EWS, first, a general agreement needs to be developed between the main stakeholders regarding the overall goal of the EWS, who will take the lead in further development and the resources (funding, man-power, regulations) that all ministries make available during the development phase. A letter of interest signed by all parties can accomplish agreement on these main aspects. This letter of interest will be the start-up step, agreeing of the concerned institutions to this letter provides the right conditions for a successful and sustainable EWS. We suggest the letter of interest makes explicit recommendations about the cooperation, fast and clear communication and sharing of information, these are the prime goals of the EWS. The letter should elaborate the following topics: the goals of the EWS should be articulated, the general approach/roadmap should be present, roles of stakeholders should be made clear, the budgets/manpower/ other input to be delivered from each ministry must be made clear. This input is being needed to make a successful implementation plan; the models in which stakeholders will work together on the development of the EWS should be made clear. This includes, in broad lines, the roles of a steering committee and operational unit, and the required support from outside organizations to establish the EWS should be indicated in or along with this letter.

\subsubsection{Organizational set-up and planning}

This entails first setting-up a steering committee and an operational unit in which ministries cooperate. The operational unit has, as a main task, to develop an implementation plan for the development of the EWS. This requires considerable technical and organizational input and it is advised that support on these issues be procured to guide this process. An inter-ministerial committee for the protection of Nile water resources is already present. It seems logical that from this committee a steering committee for the implementation of the EWS could be chosen. This committee should have the authority and responsibility for the successful setup of the operational unit that will implement the EWS. It is proposed to have the proposed EWS steering committee to work under the supervision of Higher Council of the River Nile Protection (affiliated to the Cabinet of Ministers), that will give more power and influence to the EWS committee. The EWS steering committee establishes the operational unit that develops working protocols for both the steering committee and the operational unit itself. This would need technical and legislative support from the Egyptian counterparts. After being put in operation, the role of the steering committee will be to make decisions when the operational unit 
proposes changes to the existing EWS design. The operational unit is the focus of the successful implementation of the EWS in Egypt. This unit should work out the design of the EWS in detail and should have the technical capabilities to evaluate its functions.

This unit is not only technical, but it also needs a capacity for inter-ministerial communication, law enforcement, calamity management, and organizational development. They should be determined which ministry is responsible for which part of the EWS and what measures would be needed if the responsibilities were not taken. For example, laboratory analysis will most probably be the responsibility of the $\mathrm{MoH}$, development calamity plans by the AAEE. MWRI has mechanical equipment such as cranes, excavators, tractors, concrete barriers, pumps etc. on sites with regular distribution on the Nile River at the Grand Barrages (Esna, Nag Hammadi, New Assiut and Delta Barrages), which are used for rapid rescue in crises. The telemetry system in the MWRI will be a part of the proposed EWS. The operational unit will be in its final composition, a reflection of the people responsible for the EWS tasks and EWS needs of each individual ministry. The operational unit performs all operational tasks for the development, implementation and operation of the EWS. It will be a unit that starts small in the organizational set-up and planning phase and grows while the EWS is being implemented. The operational unit reports to the steering committee, it prepares proposals to be decided upon by the steering committee. Under the direction of the operational dedicated groups may be formed in order to execute the specific tasks, e.g. groups that: make a warning by following the right procedures; identify false alarms; follow protocols and take care of responsibilities; and analyse what information are and or are not important to put in an (additional) official warning.

\subsubsection{Implementation and Testing}

It consists of getting the EWS into operation and test the results it provides. The exact ambitions might also depend on the financial possibilities, although many functions of the EWS can be reached budget neutral by shifting funds already dedicated to monitoring. Aspects that should be covered by the implementation plan include:

- Organization, mission statement, responsibilities, and protocols for steering committee and operational unit, communication protocol task and that guarantees cooperation, maintenance and operation, and legal aspects.

- Technical implementation includes, substances to be analysed, use of prediction models, monitoring locations, threshold values, false alarm identification (interpretation of results), reaction time needed and reaction time possible (depending on responsibility like laboratory analysis, interpretation of results, interpretation of information on a disaster in order to determine, whether a warning should be made), and research.

- Staffing and training include organization setup and training program.

- Financing includes the budget for the organization, operation, maintenance, and development and financing for the organization, operation, maintenance, and development.

\subsubsection{Continuous Improvement}

Learning by doing is the only way EWS will work. As well regarding the improvement of calamity management and communication as regards the monitoring program itself (Fig. 6). Lessons should especially be learned from situations where little or no damage is found, but where is being checked if everything went according to plan: did ministry A warning B within the time limit specified? And, did the ministry B start monitoring in time? In addition, progressive new techniques can be added to the repertoire of the EWS when research proves its value.

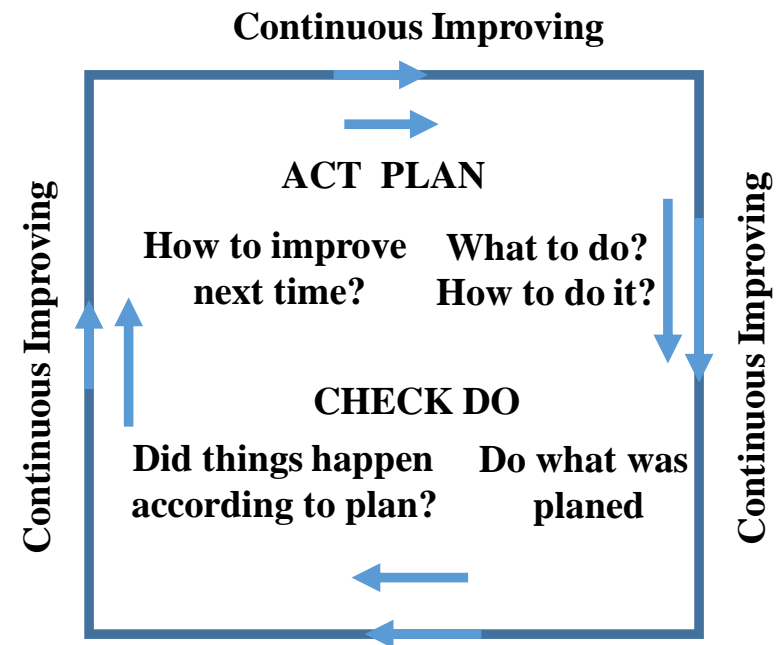

Continuous Improving

Fig. 6: EWS continuous improvement

\section{CONCLUSIONS}

The Early warning system (EWS) is more than a number of monitoring stations that automatically generate alarms when a threshold value is exceeded. It comprises of a lot of communication, cooperation, information transfer and protocols. The main conclusion for proposing of an EWS in real-time for Nile's water in Egypt is that all concerned institutions for the Nile water quality in Egypt are highly motivated to make the EWS. This is not only awareness but also a sense of ownership. EWS is not a 'new idea' but it 'should have been operational long before'. The phosphate ship accident at the beginning of 2015 made this very clear. There is a good basis for further development when four responsible ministries also have the intention to work together in the face of shared interests. The roadmap for EWS describes a process in four steps, a start-up by a letter of interest from all ministers, organizational setup, implementation and testing, and continuous improvement. Setup of the EWS, therefore, needs broad and high-level support from all involved ministries. Recommended optimum EWS locations are downstream of areas that are considered to have the highest risk (cities) in order to get the earliest warning possible and to have the longest possible reaction time to the next city (with many inhabitants) downstream as in Abou Sunbul, Idfu, Qena, Asyut, Minya, Cairo, Damanhur, Tanta, and Mansora. Judging from the 
number of analyses necessary for EWS, the current capacity of the laboratories in Egypt is sufficient. Only the monitoring program has to be changed. A change in the current monitoring program set-up and shortening of the analysis time for water samples will be resulted in improving EWS functionality. Some laboratory techniques considered relevant are not yet available: these should, prior to installation in an operational EWS, be tested and developed in a pilot station. Practice makes improvement. Working in manageable steps, starting from pilot projects is required as setting-up the EWS requires knowledge and skills that also need to be gradually developed. Finally, the establishment of a steering committee consisting of the main ministries recruited from the National Council for the protection of the Nile is a necessity as, it determines the responsibilities and takes the corrective actions, and that can optimize the EWS.

\section{Abbreviations}

GPRS: General Packet Radio Service.

GSM: Global System for Mobile Communications.

SCADA: Supervisory Control and Data Acquisition

GC-UV: Gas chromatography-Vacuum Ultraviolet Spectroscopy.

\section{Acknowledgement}

I am grateful for the special logistical and technical support delivered by the Egyptian ministers, Ministry of Water Resources and Irrigation, Ministry of Health, Ministry of Housing, Holding Company for Water and Wastewater, Ministry of Environment, Egyptian Environmental Affairs Agency, and Grontmij Nederland B.V.

\section{Conflict of Interest}

The author declares that I have no known competing financial interests or personal relationships that could have appeared to influence the work reported in this paper.

\section{References}

[1] FAO, IFAD, UNICEF, WFP and WHO. The State of Food Security and Nutrition in the World 2017. Building resilience for peace and food security, 2017, Rome.

[2] Randa B., "Water Resources Management: Alarming Crisis for Egypt", Journal of Management and Sustainability, 2014, 4, 108-124.

[3] Gabr, M., "Study of reclaimed water reuse standards and prospects in irrigation in Egypt", Port-Said Engineering Research Journal, 2020, 24: 65-75.

[4] Gabr, M. "Design Methodology of a New Surface Flow Constructed Wetland System, Case Study: East South EL-Kantara Region North Sinai, Egypt", PortSaid Engineering Research Journal, 2020, 24: 23-34.

[5] Gabr, M., Sousa H., Fattouh, E. "Groundwater quality evaluation for drinking and irrigation uses in Dayrout city Upper Egypt". Ain Shams Engineering Journal, 2020, In press article. DOI: 10.1016/j.asej.2020.05.010.

[6] NWRP, National Water Resources Plan, 2017. The national water resources plan NWRP, Ministry of Irrigation and Water Resources, Egypt.
[7] El-Ghandour H.A, Elbeltag E, Gabr, M., "Design of irrigation canals with minimum overall cost using particle swarm optimization, case study: El-Sheikh Gaber, North Sinai Peninsula, Egypt", Journal of Hydroinformatics, 2020. In press article. DOI: 10.2166/hydro.2020.199.

[8] François M., Edwin R., Doaa E.A., Waleed A.E., Mohammed F., "Irrigation improvement projects in the Nile Delta: Promises, challenges, surprises", Agricultural Water Management 216 (2019) 425435.

[9] Amaal M., Mohamed H., Mohamed. G., "Indices of water quality and metal pollution of Nile River, Egypt", National Institute of Oceanography and Fisheries, Egyptian Journal of Aquatic Research, 2017, 43, 21-29.

[10] CEDARE (Center for Environment and Development for the Arab Region and Europe) (2014), "Egypt Water Sector M\&E Rapid Assessment Report", Monitoring \& Evaluation for Water in North Africa (MEWINA) Project, Water Resources Management Program, CEDARE.

[11] WHO (World Health Organization), "Water Safety in Distribution Systems", 2014. WHO/FWC/WSH/14.03.

[12] Xiaowen D., Jianjie Z., Guihong J., Shanghong Z., "Early Warning and Forecasting System of Water Quality Safety for Drinking Water Source Areas in Three Gorges Reservoir Area, China”, Water, 2017, 9, 465.

[13] ISDR, International Strategy for Disaster Reduction and German Committee for Disaster Reduction, "Developing Early Warning Systems: A Checklist. In Proceedings of the Third International Conference on Early Warning (EWC III)", Bonn, Germany, 2006, 27-29, pp. 1-13.

[14] UN (United Nations). "Developing early warning systems: A checklist. In: EWC III Third International Conference on Early Warning From concept to action", United Nations/Inter-Agency Secretariat of the International Strategy for Disaster Reduction (UN/ISDR). Platform for the Promotion of Early Warning (PPEW) Bonn, 2006, Germany.

[15]ECJRC (European Commission Joint Research Centre), "Institute for the Protection and Security of the Citizen. Review of sensors to monitor water quality, thematic area Chemical \& Biological Risks in the Water Sector Deliverable D1-Task 1", European Reference Network for Infrastructures Protection (ERNCIP) project, 2013.

[16]CAPMAS (Central Agency for Public Mobilization and Statistics), 2018. Statistical yearbook. Cairo. Ref. No. 71-01111-20168.

[17] Egypt decree, 92/2013, "For the Protection of the Nile River and Its Waterways from Pollution", Decree of Minister of Water Resources and Irrigation no. 92 for year 2013 for the Executive Regulation of Law 48/1982, 92/2013 (in Arabic).

[18] WHO (World Health Organization), "Guidelines for the Safe Use of Wastewater, Excreta and Grey Water. In: Wastewater Use in Agriculture", Vol.2. World Health Organization, 2006, Geneva. 
[19] USEPA (United States Environmental Protection Agency), "Guidelines for Water Reuse", 2012, 600/R12/618. Washington, DC, USA.

[20] ICPR (International Commission for the Protection of the Rhine), website of the International Commission for the Protection of the Rhine. 2018.

[21] Ying L., Can C., Zexi L., Bingxin L., Jin X., Xueyuan Z., Yongchao H., "Detection and Monitoring of Oil Spills Using Moderate/High-Resolution Remote Sensing Images", Arch Environ Contam Toxicol 2017, 73:154-169, doi: 10.1007/s00244-016-0358-5.

[22] WFD, Water Framework Directive 2000/60/EC, "Directive 2000/60/EC of the European Parliament and of the Council of 23 October 2000 establishing a framework for Community action in the field of water policy", https://eur-lex.europa.eu/legalcontent/EN/TXT/PDF/?uri=CELEX:32000L0060\&f rom $=\mathrm{EN}$.

[23]WMO, World Meteorological Organization, "Guidelines on Early Warning Systems and
Application of Now casting and Warning Operations", Pws-21, No. 1559; World Meteorological Organization: Geneva, 2010, Switzerland; p. 25.

[24] ISDR, International Strategy for Disaster Reduction, "Emerging Challenges for Early Warning Systems in context of Climate Change and Urbanization", Available online: http://www.preventionweb.net/files/ 15689_ewsincontextofccandurbanization.pdf (accessed on 9 August 2017).

[25] Marco V., "The remarkable restoration of the Rhine: plural rationalities in regional water politics", Water International, 2017, 42, 207-221.

[26] Zhendi W., Merv F., Lise S., "Characterization and Source Identification of an Unknown Spilled Oil Using Fingerprinting Techniques By GC-MS and GC-FID", LCGC, 2000, 18.

\section{ANNEX 1 \\ WARNING SYSTEM FOR EGYPT NILE'S WATER QUALITY}

\begin{tabular}{|c|}
\hline SOS-Nile \\
Very Urgent \\
\hline
\end{tabular}

Reporting Authority

MRWI / HCWW / MoH / EEAA

Telephone:
Fax:

\section{Warning}

Information

Search report

All clear signal

End search report

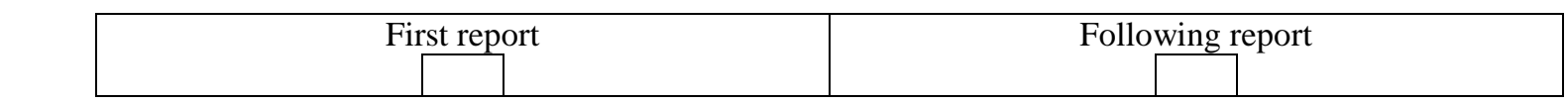

\begin{tabular}{|c|c|}
\hline Date & Annexes \\
\hline Reporting person & \\
\hline Concern & \\
\hline Reference/processing-number & Number of pages (include cover page) \\
\hline
\end{tabular}

Please hand out directly! 
ANNEX 2

REPORTING SCHEME FOR PASSING ON REPORT

SOS-Nile Very Urgent

(A) Declaration of MRWI

HCWW

$\mathrm{MoH}$

EEAA

Name

Date Time

(B) Event

Accident

\begin{tabular}{lll}
$\square \quad$ Breakdown $\quad \square$ Inceased consternation \\
\hline
\end{tabular}

(C) Place

Date

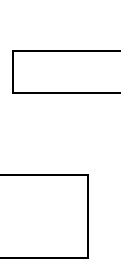

Time

River

River $(\mathrm{km})$
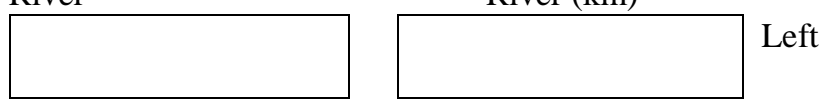

Middle

Right

Water level (cm)

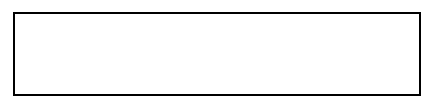

Gauging station

Run off $\left(\mathrm{m}^{3} / \mathrm{s}\right)$

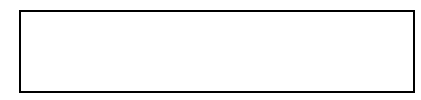

